Article

\title{
An Evaluation Study of the Capabilities of Civilian Manufacturing Enterprises Entering the Military Products Market under the Background of China's Civil-Military Integration
}

\author{
Jianzhong $\mathrm{Xu}$ and Song Zhang * \\ School of Economics and Management, Harbin Engineering University, Harbin 150001, China; \\ xujianzhongxjz@163.com \\ * Correspondence: zhangsong@hrbeu.edu.cn; Tel.: +86-1884-691-8417
}

Received: 4 February 2020; Accepted: 17 March 2020; Published: 19 March 2020

\begin{abstract}
As the Chinese government has clearly put forward the development of civil-military integration (CMI) as a national strategy, civilian manufacturing enterprises entering the military products market (CMEE-MPM) can effectively improve China's national defense science and technology capabilities and can also be an effective way for enterprises to enhance their sustainable development capabilities. However, due to the high standards and strict requirements of the national defense industry for supplier review, civilian manufacturing enterprises must evaluate their CMEE-MPM capabilities. In this study, a new evaluation and consideration model is proposed. Enterprises that plan to enter the military product market can use this model to evaluate their own CMEE-MPM capabilities. The evaluation model framework is composed of three successive parts: constructing an evaluation indicator system according to experts and enterprise experiences, calculating the weight of the indicators using an analytical hierarchy process (AHP), and evaluating CMEE-MPM capabilities using the method of fuzzy comprehensive evaluation. Finally, this study verifies the feasibility of the application of the above model by measuring the capabilities of a civilian manufacturing enterprise that wants to enter the military products market in Harbin, China. The results show that the indicator system constructed in this paper can effectively evaluate CMEE-MPM capabilities. The findings of this research can be used as a reference for the decision making of civilian manufacturing enterprises regarding whether or not to enter the military products market, and then promote the sustainable development of enterprises.
\end{abstract}

Keywords: civil-military integration; indicator system; modified Delphi method; multilevel fuzzy comprehensive evaluation; civilian manufacturing enterprises; sustainable development capabilities

\section{Introduction}

Civilian enterprises are an important part of China's national economy and the most active economic growth point in the national economy. However, due to an imperfect corporate governance structure, insufficient investment in research and development (R\&D), poor innovation ability, a large flow of talents, and irregular operation mode, the sustainable development capabilities of civilian enterprises is seriously challenged. According to the research results of the blue book of China's civilian enterprise development report, 150,000 new civilian enterprises are born in China every year, and more than 100,000 civilian enterprises die the same year. The average life span of enterprises is only 2.9 years. It can be seen that civilian enterprises should not only consider their own profitability but also pay attention to their own sustainable development capabilities. 
In fact, there are many ways for enterprises to achieve sustainable development. Enterprises can cultivate and develop their own core competitiveness, improve their innovation ability, or optimize the environment of enterprises. Of course, expanding new business areas is also an important way to achieve sustainable development. With the in-depth development of China's national defense industry, the strategy of civil-military integration (CMI) is changing from conception to practice. Currently, the military industry, which has been regarded as a restricted area in which civilian enterprises cannot invest, is gradually opening up to civilian enterprises. This also opens up a new path for civilian enterprises to expand their business fields and realize their own sustainable development. It has been reported that China's defense expenditure budget will reach 1189.9 billion RMB in 2019. According to usual practice, approximately one-third of the defense expenditure is spent on the acquisition and production of weapons and equipment, which is very attractive to military production enterprises. In the past, such defense expenditure was basically the responsibility of the twelve major domestic military industrial groups. However, in recent years, more than 3000 civilian manufacturing enterprises in China have been approved to support military products. Of course, by participating in the national defense industry, civilian manufacturing enterprises will obtain not only better economic benefits but also sustainable development. However, the strict market access system and review mechanism of the national defense industry act as a threshold for all civilian manufacturing enterprises that want to participate in the national defense industry. This threshold is a major challenge for general civilian manufacturing enterprises. Before civilian manufacturing enterprises decide whether to participate in the national defense industry, they must evaluate their civilian manufacturing enterprises entering the military products market (CMEE-MPM) capabilities. Generally, these enterprises can conduct such an evaluation in one of two ways-the first is to find a third-party consulting agency to conduct the evaluation, but the economic costs of this approach are very high, and most enterprises do not want to bear such costs; the second is self-evaluation, which is more popular with civilian manufacturing enterprises, but there is no set evaluation model framework to provide services for civilian manufacturing enterprises. Thus, the evaluation model framework in this paper can solve the problems faced by civilian manufacturing enterprises.

This study presents a new decision-making model to evaluate whether or not civilian manufacturing enterprises should enter the military products market, breaking the monopoly position of the third-party consulting agency in the evaluation of enterprises' CMEE-MPM capabilities. Civilian manufacturing enterprises that plan to enter the military products market need to complete only the questionnaire survey called the evaluation of CMEE-MPM capabilities and then use the model constructed in this paper for self-evaluation. In this way, civilian manufacturing enterprises can determine whether they can apply to be qualified as CMEE-MPM. At the same time, by using this model, civilian manufacturing enterprises can also identify their own shortcomings and the problems that need to be improved. This paper has a certain practical significance for the self-improvement of civilian manufacturing enterprises.

The remainder of this paper is organized as follows. Section 2 reviews the relevant literature on sustainable development and CMI. Section 3 builds a model for the CMEE-MPM capabilities. Section 4 reports the application of the model of CMEE-MPM. Section 5 presents a discussion, and conclusions are drawn in Section 6 . The findings can be used as a reference for decision making during the process of CMEE-MPM, as well as for civilian manufacturing enterprises in formulating sustainable operation strategies.

\section{Literature Review}

\subsection{Sustainable Development}

The concept of sustainable development was first put forward in the world conservation program that is jointly published by the International Union for Conservation of Nature (IUCN), the United Nations Environment Programme (UNEP) and the World Wildlife Fund (WWF) in 1980. This concept 
has further been widely studied. Until now, many scholars have carried out corresponding research from different perspectives. The sustainable development of nature and society $[1,2]$ is one of the fields that scholars are interested in. Yang et al. [3] classified the sustainable development indicator system according to its structure and expounded it from the four aspects of ecology, economics, sociology, and systematics. Masocha [4] discussed the relationship between social sustainability and financial performance, customer satisfaction, and employee satisfaction. Da Silva et al. [5] evaluated the sustainability of water resources from the perspective of sustainable development capital. Some scholars have also studied sustainable development from the perspective of urban and regional economy [6-8]. Yan [9] has systematically studied the storage value, total energy consumption, energy inflow and outflow, population carrying capacity, and other indicators of Tibet's main resources and put forward policy suggestions for realizing sustainable development of Tibet's resources. Wang et al. [10] studied the sustainable development of resource exhausted cities.

Meanwhile, the sustainable development of low-carbon and clean energy $[11,12]$ is also a hot topic of scholars' research. Doukas et al. [13], based on the energy policy objectives of renewable energy selection, used language variables to evaluate the sustainable development. Feng et al. [14] systematically analyzed the principles of regional water resources optimal allocation and verified the validity of the optimization model of regional water resources allocation for sustainable development by building models, designing algorithms and empirical research. In terms of the sustainable development of enterprises, scholars pay more attention to economic performance [15-17], enterprise innovation [18,19], indicator system evaluation [20-22], and enterprise strategic management [23,24].

In conclusion, scholars pay attention to a wide range of sustainable development issues, which exist in all aspects of economic and social development. However, most of the existing literature focuses on nature and society, urban and regional economy, low-carbon and clean energy. When focusing on enterprises, scholars mainly focus on economic performance, enterprise innovation, enterprise strategic management, and other aspects. There are few studies that focus on the product realization process of enterprises or focusing on civilian manufacturing enterprises under the background of military civilian integration. Therefore, this paper is helpful to enrich and expand the research field of sustainable development.

\subsection{Civil-Military Integration}

Western countries encourage market competition on the premise of ensuring national security, so scholars seldom consider whether or not civilian manufacturing enterprises are willing to enter the military products market. Scholars are more concerned with theoretical research, which has covered all aspects of the national defense economy. Scholars have studied not only the strategy [25-28] of CMI but also its system $[29,30]$. Starting from the enterprise perspective is an important direction for scholars to study. Byrne [31] proposes that arms manufacturers are only politically powerful entities in their own right and lack corporate social responsibility, which is likely responsible for the foreseeable consequences that flow from the use of their products. Akcinaroglu et al. [32] and Mahoney [33] argue that private military companies(PMCs) have an important impact on international security. They can effectively solve regional conflicts and provide defense outsourcing services while obtaining economic benefits. However, under varying market structures, the behavior of PMCs is different, so scholars should pay attention to and make use of this difference.

There are also scholars who study CMI from the perspective of medical treatment. Vie et al. [34] introduced a big data business intelligence sharing platform called the Person-Event Data Environment (PDE), and they considered that, with this platform, the critical medical and behavioral issues that affect health and well-being can be solved through military-civilian collaboration. Mooreet al. [35] and Schwab [36] explored how to improve partnerships between military and civilian surgeons and how to promote collaborative medical training for military and civilian medical professionals. The above authors stated that, through military and civilian collaboration, the mortality rate of injured soldiers can be effectively reduced and that the emergency medical system can be greatly improved. 
While more scholars have been engaged in the research of dual-use technology, Haico et al. [37] conducted in-depth research on the evolution of a social technology network related to the development of an advanced battery in the Netherlands and suggested that the establishment of "dual-capacity networks" should be part of a possible strategy toward an integrated civilian-military technology and industrial base. Watkins [38] stated that those that increase industrial capacity to absorb or share technologies from other industrial sectors are the most important dual-use investments and that more attention should be paid to building the structures and culture of civil and military technology systems. Cronberg [39] and Brandt [40] studied the new difficulties and issues faced in the processes of US military technology reconstruction and dual-use technology promotion. Molas-Gallart [41] studied the operational mechanism of dual-use technology and presented his own opinions on the four operational mechanisms. Lee et al. [42] conducted a quantitative study on the value of dual-use military technology and concluded that military technology is more valuable when the technology itself can be used in various sectors, including the civilian sector, and can be converged with technology in different fields. In addition, some scholars have studied CMI from the perspective of the supply chain [43] and arms trade [44].

As far as China is concerned, because of the high confidentiality of the national defense industry, scholars mainly study how to promote the initial integration of CMI into in-depth development, with little research on such practice and operation. Zhao et al. [45], Peng et al. [46], and Tan et al. [47] learned from developed countries' experience in the development of CMI and proposed suggestions for China on how to implement its CMI, and some scholars, such as Zhu [48], You et al. [49] and Chen et al. [50], have also studied the system, mechanism, and policy of CMI. From the point of view of national strategy, Wang et al. [51] put forward the connotation and the way to realize the capability of building a national strategic CMI system. From the perspective of the national defense industry, Du et al. [52-54] studied the construction, benefit evaluation, and level measurement of the CMI system and put forward corresponding countermeasures and suggestions. China's production of dual-use technology started relatively late compared to that of other countries. Zhang et al. [55] constructed a two-dimensional framework for the policy analysis of dual-use technology R\&D from two dimensions-policy tools and R\&D activities-and summarized the current situation and shortcomings of China's dual-use technology R\&D policy. Tai [56] stated that the progress of China's defense science, technology, and industrial system comes from the role of external technology and knowledge transfer, as well as the improvement of the defense industry's ability to absorb these inputs and convert them into localized output.

Now, more scholars are engaged in innovative research on CMI. Based on evolutionary game theory, Fang et al. [57] established an evolutionary game model of military-civilian collaborative innovation in China's satellite industry, with military and private enterprises as the main participants under bounded rationality, and summarized the factors affecting collaborative stability. Du et al. [58] believe that China's innovation-driven system should be constructed from three aspects-innovation elements, structural systems and innovation environments-which can provide guarantees for the effective implementation of the innovation-driven mechanism of CMI. From the perspective of CMI, Dong et al. [59], Zhao et al. [60], and Suo [61] separately studied the motivation of collaborative innovation, technology sharing behavior and mechanism evaluation of collaborative innovation. Fang et al. [62] studied the influencing factors of knowledge transfer in CMI and suggested that the operational mechanism has the greatest overall effect on the performance of knowledge transfer in CMI. In addition, Li et al. [63] and Zheng et al. [64] studied the problem of emergency material reserve and emergency supply prepositioning, respectively.

A literature review shows that few studies have been conducted on CMEE-MPM. Even if civilian manufacturing enterprises have the will to enter the military products market, the enterprises themselves cannot measure the matching degree of their own capabilities with the requirements of CMEE-MPM. Therefore, a set of indicator evaluation systems needs to be established to help civilian manufacturing enterprises evaluate their capabilities to enter the military products market. 


\subsection{Military Products Market}

The military products market (or military market) is the target market for the CMEE-MPM. Western scholars began to study it in the 1960s, Weidenbaum $[65,66]$ described the situation of the US military products market, the scope and main categories of the military products market. Then scholars began to subdivide the military products market, Desjardins et al. [67] studied the market situation of military flat panel displays. In recent years, with the progress of the wars in Iraq, Afghanistan and Libya, scholars have turned their research on military products market to mercenary market [68] and private defense market [34].

The early Chinese military market was a complete oligopoly, and the value of academic research was not great. Scholars like Wu [69], who only analyzed military trade from the perspective of constraints between economic and legal, gave some counter measures. Zhang et al. [70] analyzed the game behavior among the participants in the oligopoly military market. In fact, the time when scholars engaged in military products market research began with the development of China's national strategy. In 2013, Bai et al. [71] began to engage in the research of China's military products market access system. After that, Zhang et al. [72] built an effective marketing system to promote the development of China's military products market according to the characteristics of China's military products market. Jiang et al. [73] and Li et al. [74] analyzed decision-making behavior among the government, military industry enterprises, and civilian enterprises in the military products market from the perspective of game theory, which provided good suggestions for the development of CMI in China.

It can be seen that the military products market has been of concern to several scholars, but those scholars paid more attention to the game among the main bodies in the military products market. For the enterprises of CMEE-MPM, there is little research to guide civilian manufacturing enterprises on how to enter the military products market, which is the value of this paper.

\section{Model Framework}

In this paper, an evaluation model framework for the CMEE-MPM capabilities is presented, which includes the indicator system, indicator weights, and a comprehensive fuzzy evaluation method. The model framework is shown in Figure 1.

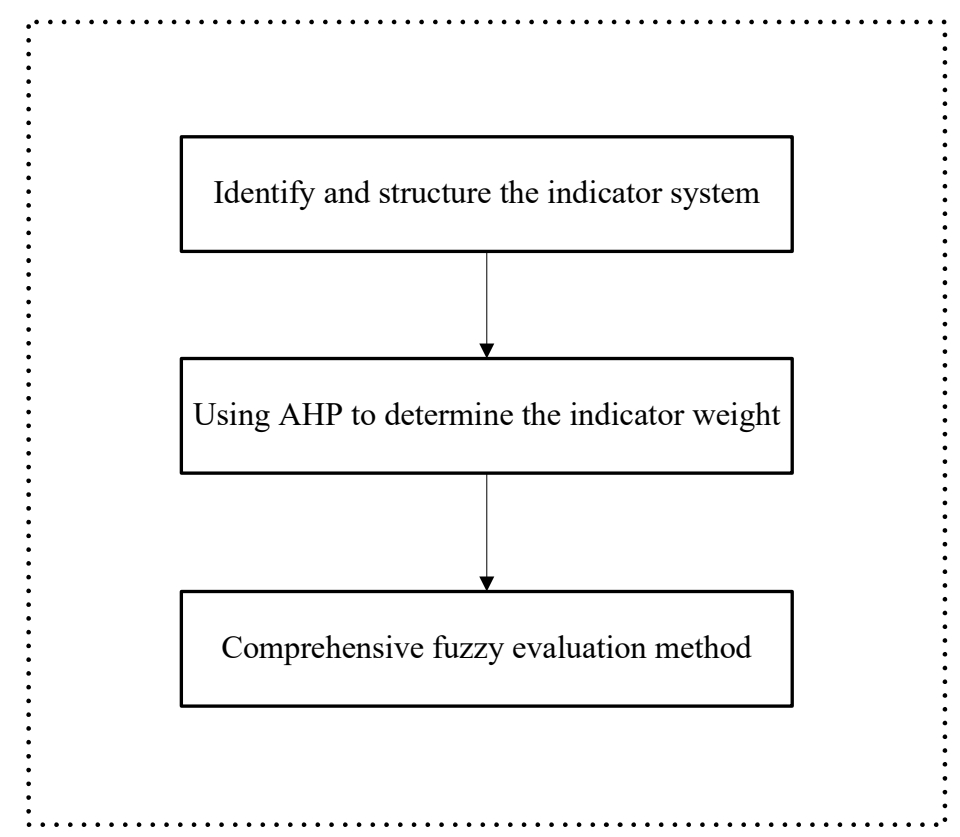

Figure 1. The model framework. 


\subsection{Proposed Indicator System}

Designing a scientific and reasonable indicator system for measuring CMEE-MPM capabilities is helpful for enterprises to accurately evaluate their own conditions for entering the military products market, and it is also use to provide decision support for their participation in national defense construction.

To effectively identify the indicator system, panels of expert advisors-consisting of scholars, military representatives and top managers of enterprises in the area of $\mathrm{CMI}-$ were convened in $\mathrm{Gu}$ Zhenkou Military-Civil Integration Innovation Demonstration Zone, Qingdao, China, to discuss and identify the evaluation indicator system. At the initial meeting, it was made clear that the indicator system was established from the perspective of manufacturing enterprises and based on the whole process of product realization. After the meeting, the advisors in each panel continued to provide feedback through correspondence. The indicator system was revised several times until it met the approval of the panels of expert advisors. The final indicator system can be seen in Table A1 in Appendix A.

For manufacturing enterprises, the management process mainly includes the service support process and product realization process, so the indicator system consists of the above two processes.

The service support process refers to the process of providing support for product realization rather than directly participating in product design, $\mathrm{R} \& \mathrm{D}$, manufacturing, and after-sales service. Moreover, the service support process includes four aspects: integrated management capacity, enterprise financial capacity, resource allocation capacity and quality management capacity. Each aspect has different intensions. (1) Integrated management capacity is the foundation of CMEE-MPM, which includes thought integration, administrative management, social recognition, and document and record management. (2) In this paper, enterprise financial capacity refers particularly to the operational capacity of enterprises engaged in military production and the benefits they can obtain from engaging in military production. (3) Resource allocation capacity refers to the situation of enterprise infrastructure and staffing allocation. (4) Quality management capacity is acquired based on China's national military quality management system standards, which mainly include system execution capacity, continuous improvement capacity, and process management capacity.

The product realization process, which is the core content of manufacturing enterprises engaged in production activities, refers to the process of product design, manufacturing, and on-site support based on market requirements, technological capabilities, and resources. The product realization process includes R\&D and process capacity, purchasing and warehousing capacity, production and manufacturing capacity, and maintenance and after-sales service guarantee capacity.

\subsection{Determine the Indicator Weights}

To ensure the validity and continuity of the research, this paper refers to Parente and Anderson's [75] proposition, and we complete the determination of the indicator weights via the following steps.

In Step 1, an expert panel is formed.

For the selection of experts, we select from the experts who participated in the initial meeting, and we are having a total of 16 experts. The specific distribution of experts can be seen in Table 1.

In Step 2, the questionnaire survey among experts was conducted.

Among the 16 experts, 10 experts were investigated by mail, four experts by fax, and two experts by face-to-face on-site interviews. Sixteen questionnaires were distributed, and 16 were returned, providing us with a response rate of $100 \%$.

In Step 3, the analytical hierarchical process (AHP) was used to determine the indicator weights. The determination of the indicator weights takes the following steps:

First, we define the criteria for CMEE-MPM capabilities (given in Table A1 in Appendix A). 
Table 1. Distribution of the experts.

\begin{tabular}{cccc}
\hline Source of Experts & Members & Quantity & Percentage \\
\hline Academic circles & Two members of academic institutions & 2 & 12.50 \\
\hline Government circles & $\begin{array}{c}\text { Two members from the office of civil } \\
\text { military integration and two members of } \\
\text { Gu Zhenkou military-civilian integration } \\
\text { innovation demonstration zone in Qingdao }\end{array}$ & 4 & 25.00 \\
\hline Business circles & $\begin{array}{c}\text { Two members of the science and technology } \\
\text { park, three members of A company, and } \\
\text { three members of B company * }\end{array}$ & 8 & 50.00 \\
\hline Military circles & Two members from the military & 2 & 12.50 \\
\hline Total & & 16 & 100 \\
\hline
\end{tabular}

Second, factors of the same level in the hierarchical structure model are compared by using the nine importance levels, and the assignments are provided by Saaty (Table 2). The scaling values are obtained with the Delphi method, and then, the results of the comparisons are put into matrix form; thus, an adjustment matrix is formed (Table 3 ).

Table 2. Criteria for judging scale 1-9.

\begin{tabular}{cc}
\hline Scale & Meaning \\
\hline 1 & the two factors $\mathrm{B}_{\mathrm{i}}$ and $\mathrm{B}_{\mathrm{j}}$ have the same importance as each other \\
3 & $\mathrm{~B}_{\mathrm{i}}$ is slightly more important than $\mathrm{B}_{\mathrm{j}}$ \\
5 & $\mathrm{~B}_{\mathrm{i}}$ is obviously more important than $\mathrm{B}_{\mathrm{j}}$ \\
7 & $\mathrm{~B}_{\mathrm{i}}$ is strongly more important than $\mathrm{B}_{\mathrm{j}}$ \\
9 & $\mathrm{~B}_{\mathrm{i}}$ is extremely more important than $\mathrm{B}_{\mathrm{j}}$ \\
$2,4,6,8$ & the median value of the adjacent judgment mentioned above \\
Reciprocal & if $\mathrm{B}_{\mathrm{i}} / \mathrm{b}_{\mathrm{j}}=\mathrm{a}_{\mathrm{ij}}$, then $\mathrm{B}_{\mathrm{j}} / \mathrm{B}_{\mathrm{i}}=1 / \mathrm{a}_{\mathrm{ij}}$ \\
\hline
\end{tabular}

Table 3. Judgment matrix.

\begin{tabular}{ccccc}
\hline $\mathbf{A}_{\mathbf{k}}$ & $\mathbf{B}_{\mathbf{1}}$ & $\mathbf{B}_{\mathbf{2}}$ & $\ldots$ & $\mathbf{B}_{\mathbf{n}}$ \\
\hline $\mathrm{B}_{1}$ & $\mathrm{~b}_{11}$ & $\mathrm{~b}_{12}$ & $\ldots$ & $\mathrm{b}_{1 \mathrm{n}}$ \\
$\mathrm{B}_{2}$ & $\mathrm{~b}_{21}$ & $\mathrm{~b}_{22}$ & $\ldots$ & $\mathrm{b}_{2 \mathrm{n}}$ \\
$\ldots$ & $\ldots$ & $\ldots$ & $\ldots$ & $\ldots$ \\
$\mathrm{B}_{\mathrm{n}}$ & $\mathrm{b}_{\mathrm{n} 1}$ & $\mathrm{~b}_{\mathrm{n} 2}$ & $\ldots$ & $\mathrm{b}_{\mathrm{nn}}$ \\
\hline
\end{tabular}

Third, the weights of factors at the same level (single ranking at the same level) are calculated. We use the judgment matrix to calculate the order weight value of the relative importance of a factor of the same level to a factor of the upper level, and the process of calculating weights can be reduced to the problem of calculating the eigenvalues and eigenvectors of the judgment matrix; i.e., for judgment matrix $B$, the calculation satisfies the requirement.

$$
\mathrm{BW}=\lambda_{\max } \mathrm{W}
$$

In the formula, $\lambda_{\max }$ is the largest eigenvalue of $\mathrm{B}, \mathrm{W}$ is the normalized eigenvector corresponding to $\lambda_{\max }$, and the component $\mathrm{W}_{\mathrm{i}}$ of $\mathrm{W}$ is the weight of single ranking of the corresponding factors.

Finally, the consistency of the matrix is checked, and its consistency index (CI) is calculated.

$$
\mathrm{CI}=\frac{\lambda_{\max }-\mathrm{n}}{\mathrm{n}-1}
$$


The smaller the value of $\mathrm{CI}$ is, the greater the consistency. When $\mathrm{CI}=0$, the matrix has complete consistency, and when the value of $\mathrm{CI}$ is close to 0 , the matrix has satisfactory consistency; the larger the value of $\mathrm{CI}$ is, the more serious the inconsistency. To measure the value of $\mathrm{CI}$, we need to introduce the random consistency index (RI).

$$
\mathrm{RI}=\frac{\mathrm{CI}_{1}+\mathrm{CI}_{2}+\cdots+\mathrm{CI}_{\mathrm{n}}}{\mathrm{n}}
$$

The RI is related to the order of the judgment matrix. Generally, the larger the order of the matrix is, the more the probability of the consistency random deviation increases with the order of the matrix. The corresponding relationship is shown in Table 4.

Table 4. The standard value of mean random consistency index (RI).

\begin{tabular}{ccccccccccc}
\hline Matrix Order & $\mathbf{1}$ & $\mathbf{2}$ & $\mathbf{3}$ & $\mathbf{4}$ & $\mathbf{5}$ & $\mathbf{6}$ & $\mathbf{7}$ & $\mathbf{8}$ & $\mathbf{9}$ & $\mathbf{1 0}$ \\
\hline RI & 0 & 0 & 0.58 & 0.9 & 1.12 & 1.24 & 1.32 & 1.41 & 1.45 & 1.49 \\
\hline
\end{tabular}

Considering that this deviation in consistency may be caused by random factors, it is necessary to compare CI with RI to obtain the test coefficient (CR) when checking whether the judgment matrix has satisfactory consistency.

$$
\mathrm{CR}=\frac{\mathrm{CI}}{\mathrm{RI}}
$$

When $C R<0.10$, the judgment matrix has satisfactory consistency; otherwise, we need to revise the Delphi method and then adjust the judgment matrix.

We use software to perform the above calculation process. Through this calculation, we find that the consistency test on the system execution capability and process management capability of the judgment matrix failed. After analysis, the practical experience related to system execution capability and process management capability is more important. When using the Delphi method for scoring, experts in academic circles and government circles lack practical experience, so their scores are low. From the perspective of manufacturing enterprises, the scores of business circles and military circles are more suitable for the actual situation. Therefore, we decided to use the weight coefficient to adjust the scores of the indicators of management review and qualification rate of one-time inspection of reworked and repaired products. The evaluation weight coefficient of experts in academic circles and government circles is set to 0.6 , and the evaluation weight coefficient of those in business circles and military circles is set to 0.4 . Then, we perform the consistency test again; after operation, the indicators pass the consistency test, and we obtain the final indicator weights for each level, as shown in Table A2 in Appendix A.

\subsection{Multilevel Fuzzy Comprehensive Evaluation}

In reality, many indicators cannot be quantitatively evaluated, which forces decision makers to face uncertain and fuzzy information. In this paper, the multilevel fuzzy evaluation model is used to evaluate CMEE-MPM capabilities to determine whether civilian manufacturing enterprises can enter the military products market. The multilevel fuzzy comprehensive evaluation takes the following steps.

Step 1: Construction of the evaluation object's factor set.

In multilevel fuzzy comprehensive evaluation, the set of evaluation objects is $U=\left\{\mathrm{u}_{1}, \mathrm{u}_{2}, \mathrm{u}_{3}, \ldots, \mathrm{u}_{\mathrm{p}}\right\}$. That is, there are $p$ first-level evaluation indicators. In our case, the first level has 50 evaluation objects, so all 50 evaluation objects form the evaluation object's factor set.

That is, $\mathrm{U}_{1}=\left\{\mathrm{u}_{1}, \mathrm{u}_{2}, \mathrm{u}_{3}, \ldots, \mathrm{u}_{50}\right\}$.

In addition, we can obtain the sets of evaluation objects at all levels of the multilevel evaluation.

Step 2: Determination of the comment-level set. 
The evaluation set $\mathrm{V}$ is a set of evaluation grades, and each grade corresponds to a fuzzy subset. To effectively identify and distinguish CMEE-MPM capabilities, we use a three-point method to determine the evaluation levels, which are good, average, and poor.

That is, $\mathrm{V}=$ \{poor, average, good $\}$.

Step 3: Determination of membership function.

The membership function is constructed by using the comment set to clarify the subordination of each evaluation factor in the evaluation. There are many membership functions (fuzzy distribution), such as rectangular distribution, normal distribution, trapezoidal distribution, k-order parabolic distribution, and Cauchy distribution. We can choose one or several of these functions according to the actual situation. In this paper, the typical membership function introduced by Liu [76] is used to construct the membership function of the comment set.

That is, the membership function that the comment is "poor."

$$
\widetilde{\mathrm{U}_{\mathrm{p}}}=\left\{\begin{array}{cc}
1 & \mathrm{x} \leq 1 \\
1-2\left(\frac{\mathrm{x}-1}{2}\right)^{2} & 1<x \leq 2 \\
2\left(\frac{\mathrm{x}-3}{2}\right)^{2} & 2<x \leq 3 \\
0 & \mathrm{x}>3
\end{array}\right.
$$

The membership function that the comment is "average"

$$
\widetilde{\mathrm{U}_{\mathrm{A}}}=\left\{\begin{array}{cc}
0 & \mathrm{x}<1 \\
2\left(\frac{\mathrm{x}-1}{2}\right)^{2} & 1<x \leq 2 \\
1-2\left(\frac{\mathrm{x}-3}{2}\right)^{2} & 2<x \leq 4 \\
2\left(\frac{\mathrm{x}-5}{2}\right)^{2} & 4<x \leq 5 \\
0 & \mathrm{x}>5
\end{array}\right.
$$

The membership function that the comment is 'good'

$$
\widetilde{\mathrm{U}_{\mathrm{G}}}=\left\{\begin{array}{cc}
0 & \mathrm{x} \leq 3 \\
2\left(\frac{\mathrm{x}-3}{2}\right)^{2} & 3<x \leq 4 \\
1-2\left(\frac{\mathrm{x}-5}{2}\right)^{2} & 4<x \leq 5 \\
1 & \mathrm{x}>5
\end{array}\right.
$$

Step 4: Selection of the survey respondents and the questionnaire.

The survey respondents come from enterprises that want to evaluate their CMEE-MPM capabilities. To ensure the effectiveness of the evaluation results of these enterprises, the respondents who are selected should be purposefully classified.

Step 5: The fuzzy relation matrix.

Through the evaluation of each indicator by survey respondents, we can obtain the membership degree of each level of the fuzzy subset by using the membership function and then obtain the fuzzy relation matrix. For multilevel fuzzy comprehensive evaluation, we can obtain the second-level fuzzy relation matrix, which is composed of the first-level judgment vector.

Step 7: Selection of the fuzzy composition operator.

The principle of fuzzy comprehensive evaluation is fuzzy transform, and the model is as follows:

$$
\mathrm{A}^{\circ} \mathrm{R}=\left(\mathrm{a}_{1}, \mathrm{a}_{2}, \ldots, \mathrm{a}_{\mathrm{p}}\right)^{\circ}\left(\begin{array}{cccc}
\mathrm{r}_{11} & \mathrm{r}_{12} & \ldots & \mathrm{r}_{1 \mathrm{~m}} \\
\mathrm{r}_{21} & \mathrm{r}_{22} & \ldots & \mathrm{r}_{2 \mathrm{~m}} \\
\vdots & \vdots & & \vdots \\
\mathrm{r}_{\mathrm{p} 1} & \mathrm{r}_{\mathrm{p} 2} & \ldots & \mathrm{r}_{\mathrm{pm}}
\end{array}\right)=\left(\mathrm{b}_{1}, \mathrm{~b}_{2}, \ldots \mathrm{b}_{\mathrm{m}}\right)
$$


where" $\bigcirc$ " denotes a fuzzy composition operator. In general, the fuzzy composition operators include the following:

(1) $\mathrm{M}(\wedge, \vee)$ operator

$$
S_{k}=\underbrace{m}_{j=1}\left(\mu_{j} \wedge r_{j k}\right)=\max _{1 \leq j \leq m}\left\{\min \left(\mu_{j}, r_{j k}\right)\right\}, k=1,2, \ldots, n
$$

(2) $\mathrm{M}(\bullet, \vee)$ operator

$$
S_{k}=\sum_{j=1}^{m}\left(\mu_{j} \cdot r_{j k}\right)=\max _{1 \leq j \leq m}\left\{u_{j}, r_{j k}\right\}, k=1,2, \ldots, n
$$

(3) $\mathrm{M}(\wedge, \oplus)$ operator

$$
\mathrm{S}_{\mathrm{k}}=\min \left\{1, \sum_{\mathrm{j}=1}^{\mathrm{m}} \min \left(\mu_{\mathrm{j}}, \mathrm{r}_{\mathrm{jk}}\right)\right\}, \mathrm{k}=1,2, \ldots, \mathrm{n}
$$

(4) $\mathrm{M}(\bullet, \oplus)$ operator

$$
S_{k}=\min \left(1, \sum_{j=1}^{m} \mu_{j} r_{j k}\right), k=1,2, \ldots, n
$$

When we select the fuzzy composition operator, it is more appropriate to use multiplication to reflect the role of the weights and to use bounded operation and normal operation to reflect entirety. In this way, it is more suitable to optimize the overall index from a comprehensive point of view. Therefore, a fuzzy composition operator $\mathrm{M}(\bullet, \oplus)$ is generally chosen as a fuzzy composition operator.

Step 8: Analysis of the results of fuzzy comprehensive evaluation.

Let the fuzzy comprehensive evaluation vector be B; then,

$$
\mathrm{B}=\left(\mathrm{b}_{1}, \mathrm{~b}_{2}, \mathrm{~b}_{3}\right)
$$

Moreover, to obtain a precise evaluation result, the comment levels can be set as a variable range. Here, we refer to the qualification examination of the equipment manufacturing unit and the implementation method of the scientific research and production license for weapons and equipment of China and set 0-60(poor), 60-80(average), and 80-100(good). Then, the comment-level matrix $\mathrm{P}$ can be obtained by calculating its group median value, i.e.,P $=(50,70,90)^{\prime}$. The comprehensive evaluation function $S$ is obtained by multiplying the evaluation vector $B$ bythe evaluation grade matrix $P$.

That is, $\mathrm{S}=\mathrm{B} \cdot \mathrm{P}$.

According to the value of $S$, we can obtain the range of $S$, and then, the final evaluation result for manufacturing enterprises that want to enter the military products market can be obtained.

\section{Application}

We now apply the proposed model framework to an empirical case company with the aim of assessing its CMEE-MPM capabilities.

\subsection{Company Background}

C Company is a civilian manufacturing enterprise engaged in the $R \& D$, production, and manufacturing of an integrated electronic control system for marine diesel engines and marine fire-fighting system products. For the company's sustainable development and to better meet national strategic needs, the company intends to participate in the construction of the national defense industry 
and engage in military production as a civilian manufacturing enterprise. However, due to the dualistic separation structure between the military and civilians in China, it is still difficult for civilian enterprises to enter the military products market. In view of whether to enter the military products market, enterprise management has been hesitant. This study, based on the above situation and from the perspective of civilian manufacturing enterprises, provides the necessary decision support for business managers.

\subsection{Application Results}

As mentioned in Section 3, based on the given indicator system and indicator weights, we use multilevel fuzzy comprehensive evaluation to evaluate the empirical company's CMEE-MPM capabilities.

Now, all we have to do is obtain respondents from the empirical company, and we purposefully classify the respondents according to the requirements of Step 4 in Section 3.3. The distribution of specific survey respondents can be seen in Table 5 .

Table 5. The distribution of survey respondents.

\begin{tabular}{|c|c|c|c|}
\hline $\begin{array}{l}\text { Source of Survey } \\
\text { Respondents }\end{array}$ & Members & Quantity & Percentage \\
\hline Strategic planning level & $\begin{array}{l}\text { Four members are the general } \\
\text { manager, vice president of } \\
\text { production, vice president of design, } \\
\text { and vice president of finance }\end{array}$ & 4 & 13.33 \\
\hline Tactical planning level & $\begin{array}{l}\text { Ten members of the middle level } \\
\text { leaders from the whole process of } \\
\text { product realization, including } \\
\text { administration, finance, design, } \\
\text { production, planning, procurement, } \\
\text { sales, after-sales, quality } \\
\text { management, and human resources }\end{array}$ & 10 & 33.33 \\
\hline Operation management level & $\begin{array}{l}\text { One member of administration, one } \\
\text { member of finance, five members of } \\
\text { R\&D, five members of production, } \\
\text { one member of procurement, two } \\
\text { members of after-sales, and one } \\
\text { member of quality }\end{array}$ & 16 & 53.33 \\
\hline Total & & 30 & 100.00 \\
\hline
\end{tabular}

All 30 survey respondents were investigated with face-to-face on-site interviews. Thirty questionnaires were distributed, and 30 were returned, giving us a response rate of $100 \%$.

Then, we can obtain the evaluation results of each level following Steps 5-8 in Section 3.3, and the evaluation results of each level are shown in Tables 6-9.

From Table 9, we can obtain the evaluation vector B; i.e., $B=(0.0065,0.0626,0.9309)$. The comprehensive evaluation function $S$ is obtained by multiplying the evaluation vector $B$ by the evaluation grade matrix $P$.

That is, $\mathrm{S}=\mathrm{B} \cdot \mathrm{P}=(0.0065,0.0626,0.9309) \times(50,70,90)^{\prime}=88.4880$.

According to the value of $S$, we know that $S \in(80 \sim 100)$, and the final evaluation result of the empirical company is good. 
Table 6. The first level comprehensive evaluation results.

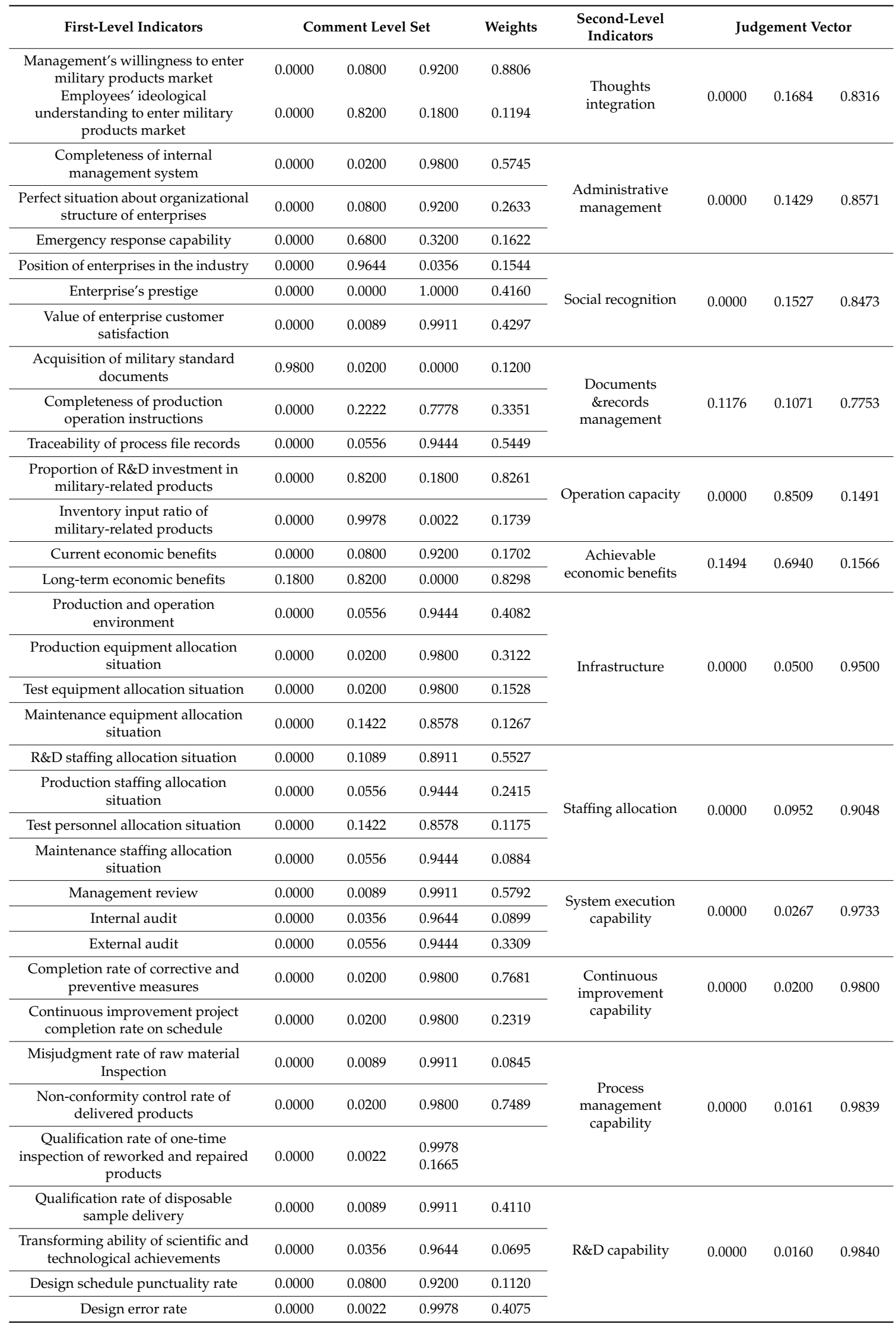


Table 6. Cont

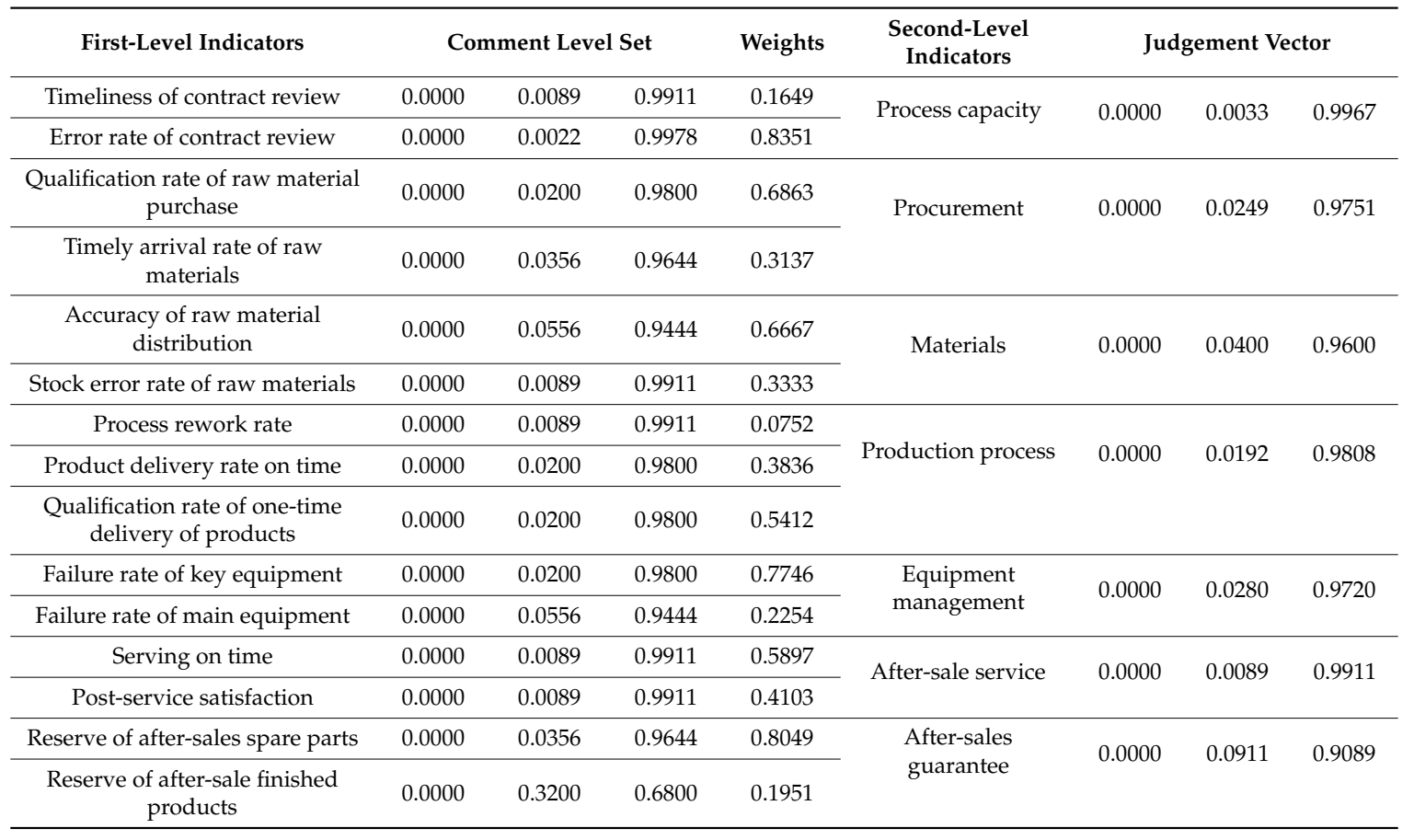

Table 7. The second level comprehensive evaluation results.

\begin{tabular}{|c|c|c|c|c|c|c|c|c|}
\hline $\begin{array}{l}\text { Second-Level } \\
\text { Indicators }\end{array}$ & \multicolumn{3}{|c|}{ Comment Level Set } & \multirow{2}{*}{$\begin{array}{c}\text { Weights } \\
0.0675\end{array}$} & \multirow[t]{2}{*}{ Third-Level Indicators } & \multicolumn{3}{|c|}{ Judgement Vector } \\
\hline Thoughts integration & 0.0000 & 0.1684 & 0.8316 & & & \multirow{4}{*}{0.0298} & \multirow{4}{*}{0.1370} & \multirow{4}{*}{0.8332} \\
\hline $\begin{array}{l}\text { Administrative } \\
\text { management }\end{array}$ & 0.0000 & 0.1429 & 0.8571 & 0.5252 & \multirow{3}{*}{$\begin{array}{l}\text { Integrated management } \\
\text { capacity }\end{array}$} & & & \\
\hline Social recognition & 0.0000 & 0.1527 & 0.8473 & 0.1539 & & & & \\
\hline $\begin{array}{c}\text { Documents \&records } \\
\text { management }\end{array}$ & 0.1176 & 0.1071 & 0.7753 & 0.2534 & & & & \\
\hline Operation capacity & 0.0000 & 0.8509 & 0.1491 & 0.3038 & \multirow[b]{2}{*}{$\begin{array}{l}\text { Enterprise financial } \\
\text { capacity }\end{array}$} & \multirow{2}{*}{0.1040} & \multirow{2}{*}{0.7417} & \multirow{2}{*}{0.1543} \\
\hline $\begin{array}{c}\text { Achievable economic } \\
\text { benefits }\end{array}$ & 0.1494 & 0.6940 & 0.1566 & 0.6962 & & & & \\
\hline Infrastructure & 0.0000 & 0.0500 & 0.9500 & 0.5000 & \multirow{2}{*}{$\begin{array}{l}\text { Resource allocation } \\
\text { capacity }\end{array}$} & \multirow{2}{*}{0.0000} & \multirow{2}{*}{0.0726} & \multirow{2}{*}{0.9274} \\
\hline Staffing allocation & 0.0000 & 0.0952 & 0.9048 & 0.5000 & & & & \\
\hline $\begin{array}{l}\text { System execution } \\
\text { capability }\end{array}$ & 0.0000 & 0.0267 & 0.9733 & 0.3333 & \multirow{3}{*}{$\begin{array}{l}\text { Quality management } \\
\text { ability }\end{array}$} & \multirow{3}{*}{0.0000} & \multirow{3}{*}{0.0209} & \multirow{3}{*}{0.9791} \\
\hline $\begin{array}{l}\text { Continuous } \\
\text { improvement capability }\end{array}$ & 0.0000 & 0.0200 & 0.9800 & 0.3333 & & & & \\
\hline $\begin{array}{c}\text { Process management } \\
\text { capability }\end{array}$ & 0.0000 & 0.0161 & 0.9839 & 0.3333 & & & & \\
\hline R\&D capability & 0.0000 & 0.0160 & 0.9840 & 0.7333 & \multirow{2}{*}{$\begin{array}{l}\text { R\&D and process } \\
\text { capability }\end{array}$} & \multirow{2}{*}{0.0000} & \multirow{2}{*}{0.0126} & \multirow{2}{*}{0.9874} \\
\hline Process capacity & 0.0000 & 0.0033 & 0.9967 & 0.2667 & & & & \\
\hline Procurement & 0.0000 & 0.0249 & 0.9751 & 0.7419 & \multirow{2}{*}{$\begin{array}{c}\text { Purchasing and } \\
\text { warehousing capacity }\end{array}$} & \multirow{2}{*}{0.0000} & \multirow{2}{*}{0.0288} & \multirow{2}{*}{0.9712} \\
\hline Materials & 0.0000 & 0.0400 & 0.9600 & 0.2581 & & & & \\
\hline Production process & 0.0000 & 0.0192 & 0.9808 & 0.5000 & \multirow{2}{*}{$\begin{array}{c}\text { Production and } \\
\text { manufacturing capacity }\end{array}$} & \multirow{2}{*}{0.0000} & \multirow{2}{*}{0.0236} & \multirow{2}{*}{0.9764} \\
\hline $\begin{array}{l}\text { Equipment } \\
\text { management }\end{array}$ & 0.0000 & 0.0280 & 0.9720 & 0.5000 & & & & \\
\hline After-sale service & 0.0000 & 0.0089 & 0.9911 & 0.5000 & \multirow{2}{*}{$\begin{array}{l}\text { Maintenance and } \\
\text { after-sales service } \\
\text { guarantee capability }\end{array}$} & \multirow{2}{*}{0.0000} & \multirow{2}{*}{0.0500} & \\
\hline After-sales guarantee & 0.0000 & 0.0911 & 0.9089 & 0.5000 & & & & 0.1000 \\
\hline
\end{tabular}


Table 8. The Third level comprehensive evaluation results.

\begin{tabular}{|c|c|c|c|c|c|c|c|c|}
\hline \multirow{2}{*}{$\begin{array}{c}\text { Third-Level Indicators } \\
\text { Integrated management capacity }\end{array}$} & \multicolumn{3}{|c|}{ Comment Level Set } & \multirow{2}{*}{$\begin{array}{l}\text { Weights } \\
0.3708 \\
\end{array}$} & \multirow{5}{*}{$\begin{array}{c}\begin{array}{c}\text { Forth-Level } \\
\text { Indicators }\end{array} \\
\begin{array}{c}\text { Service support } \\
\text { process }\end{array}\end{array}$} & \multicolumn{3}{|c|}{ Judgement Vector } \\
\hline & 0.0298 & 0.1370 & 0.8332 & & & & & \\
\hline Enterprise financial capacity & 0.1040 & 0.7417 & 0.1543 & 0.1205 & & 0.0236 & 0.1616 & 0.8148 \\
\hline Resource allocation capacity & 0.0000 & 0.0726 & 0.9274 & 0.2073 & & & & \\
\hline Quality management ability & 0.0000 & 0.0209 & 0.9791 & 0.3013 & & & & \\
\hline R\&D and process capability & 0.0000 & 0.0126 & 0.9874 & 0.4041 & \multirow{4}{*}{$\begin{array}{l}\text { Product } \\
\text { realization process }\end{array}$} & \multirow{4}{*}{0.0000} & \multirow{4}{*}{0.0249} & \multirow{4}{*}{0.9751} \\
\hline Purchasing and warehousing capacity & 0.0000 & 0.0288 & 0.9712 & 0.0960 & & & & \\
\hline Production and manufacturing capacity & 0.0000 & 0.0236 & 0.9764 & 0.3019 & & & & \\
\hline $\begin{array}{l}\text { Maintenance and after-sales service } \\
\text { guarantee capability }\end{array}$ & 0.0000 & 0.0500 & 0.9500 & 0.1980 & & & & \\
\hline
\end{tabular}

Table 9. The Forth level comprehensive evaluation results.

\begin{tabular}{|c|c|c|c|c|c|c|c|c|}
\hline \multirow{2}{*}{$\begin{array}{l}\text { Forth-Level Indicators } \\
\text { Service support process }\end{array}$} & \multicolumn{3}{|c|}{ Comment Level Set } & \multirow{2}{*}{$\begin{array}{l}\text { Weights } \\
0.27586 \\
\end{array}$} & \multirow{3}{*}{$\begin{array}{c}\text { Fifth-Level Indicators } \\
\text { The capabilities of enterprises } \\
\text { entering military products market }\end{array}$} & \multicolumn{3}{|c|}{ Judgement Vector } \\
\hline & 0.0236 & 0.1616 & 0.8148 & & & 0.0065 & 0.0626 & 0.9309 \\
\hline Product realization process & 0.0000 & 0.0249 & 0.9751 & 0.72414 & & & & \\
\hline
\end{tabular}

\section{Discussions}

For civilian manufacturing enterprises, entering the military products market is a major decision, as it is crucial to the sustainability and future development of these enterprises. The calculated results show that for manufacturing enterprises, the quality of the product realization process has a great influence on whether they can enter the military products market. The results suggest that, from the perspective of the whole process of product realization, the empirical company should prioritize participating in the military products market.

In fact, according to the final evaluation results, the top manager of the empirical company decided to mobilize all resources of the enterprise to participate in the military products market. To ensure the effective promotion of the enterprise in participating in the military products market, the top manager first obtains the evaluation value of the second-level indicator by the value of the judgment vector in Table 6.The evaluation values of the secondary indicators are shown in Figure 2.

Figure 2 shows that the scores of the service support process are relatively low, especially those of achievable economic benefits, operation capacity, and document and record management. The top manager analyzed the causes as follows. In terms of the actual situation of private enterprises participating in the military products market, it is very difficult for enterprises to obtain economic benefits in the short term because the pricing of military products is not floating but rather follows a "pricing cost plus" mode or "target price management" mode, which is led by the military. In the early stage of military product manufacturing, enterprises need to invest a relatively large number of human and material resources to match the performance indicators of military products, which leads to the relatively high cost of the products produced at the beginning, so the score of achievable economic benefits is low.

It is also understandable that the operation ability score is low. The purpose of such an entity enterprise is to make a profit. In the early stage of participating in the military products market, the enterprise will go through the process of prototype trial production, product finalization, small-scale mass production, batch production, etc., and its sales volume expectation for military products is difficult to grasp. If too much R\&D and inventory are put into the enterprise, then it is not good for the turnover of the enterprise, so the survey respondents will reduce the expected value of the operational capability score.

Document and record management is the key rectification project of the enterprise, which has not only a low score in this evaluation but also problems in the internal and external audits. These problems are mainly manifested in the following aspects. 
1. The controllability of production documents is poor. Uncontrolled documents appear in the production workshop and are used by field personnel.

2. The guidance of production documents is poor. It is difficult to realize the operation content in individual documents under the existing conditions.

3. The consistency of production documents is poor. The same or similar content sometimes appears in different documents, but due to the documents being drawn up at different times, the content is inconsistent and even conflicting.

4. The traceability of records is poor. The production records for individual parts cannot be traced back to their process processors.

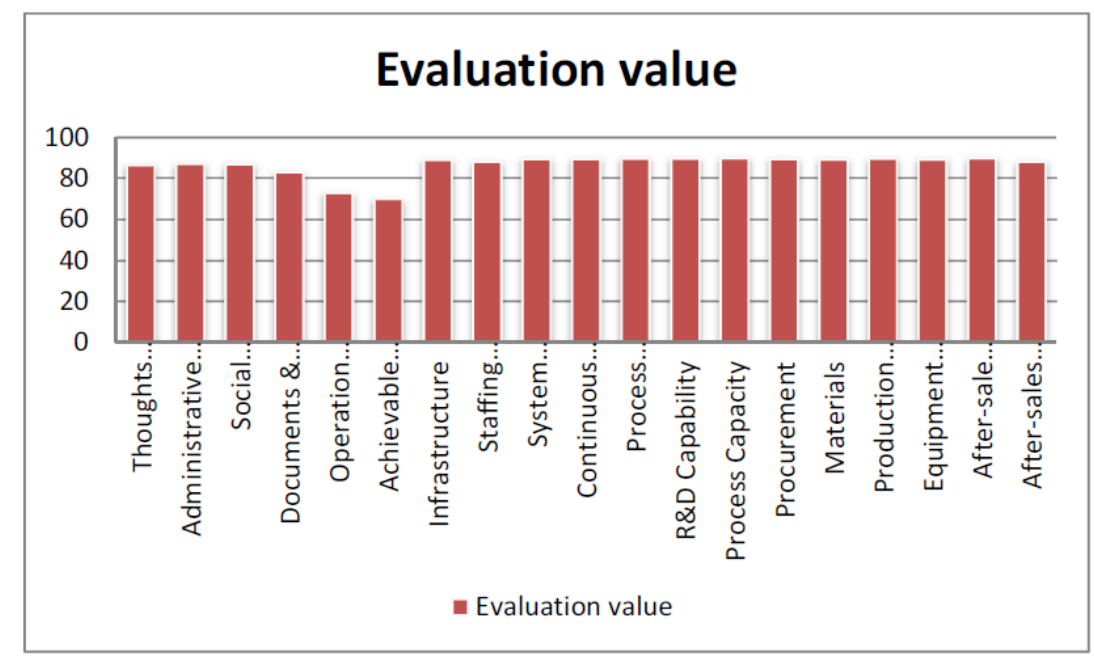

Figure 2. The evaluation values of the secondary indicators.

In view of the above problems, the enterprise has taken the following rectification measures.

1. A meeting regarding document and record problem rectification was held and decided to establish the rectification team, with the top manager as the team leader and the heads of each department as team members; this meeting also clarified the self-inspection content of each department's documents.

2. All departments checked the existing documents of their departments and summarized the existing problems within the limited period.

3. The top manager held the second meeting regarding document and record problem rectification to confirm the cleaning, cancellation and revision content of the problem documents and to assign each task to a specific responsible person.

4. The quality department recycled and voided the existing documents and records of each department, reissued the revised documents and records, and tracked the operation effect of the feedback documents and records.

In fact, the document record is the information carrier with reference value that is formed in the process of enterprise production, operation, and management. By tracing and statistics of the document record, the enterprise can constantly improve itself. Therefore, it can be said that the document record is not only the internal requirement to improve the soft power of the enterprise, but also the guarantee of the sustainable development of the enterprise. Through its own rectification, the empirical enterprise has improved the document and record management process, and after nearly six months of actual operation, it began to apply for military production qualification and obtained the qualification of being an equipment manufacturer in December 2018, which was an important step for the enterprise in participating in military competition. Now, the enterprise is actively applying for a 
license for the scientific research and production of weapons and equipment and the confidentiality qualification certificate. It is believed that the enterprise will complete the established plan in the near future and enter the military products market. It can be seen that this paper provides decision support (i.e., whether to enter the military products market) for enterprise decision makers and a reference for enterprise decision makers to effectively identify the influencing factors of sustainable development of enterprises. Therefore, it can be said that this paper has good practical significance.

\section{Conclusions}

The sustainable development of an enterprise is a process where by an enterprise seeks the means for its own survival and permanent development. In this process, enterprise decisionmakers should consider not only the realization of its own business objectives but also the needs of future development. This paper provides both a direction of enterprise development for enterprise decisionmakers and a method to identify the influencing factors of enterprise sustainable development for enterprise decisionmakers.

To propose a model for civilian manufacturing enterprises to evaluate their CMEE-MPM capabilities, this paper sets up an evaluation framework based on the whole process of product realization and organizes the evaluation criteria and corresponding evaluation indicators. Through the AHP and modified Delphi method, we obtained the weight of each evaluation indicator in the evaluation system and performed empirical research with the help of the fuzzy comprehensive evaluation method. This empirical study shows that the indicator system we set up has effectively grasped and solved the decision-making problem concerning whether or not civilian manufacturing enterprises should enter the military products market. In practical applications, this indicator system can provide decision support for top managers and identify bottleneck problems in the process of entering into the military products market. In addition to solving the urgent affairs of enterprises, this system can also provide theoretical support for improving the core of enterprises' competitiveness and sustainable development.

Although this paper has achieved some important results, in fact, CMEE-MPM remains a very complicated process, which requires not only the efforts of the enterprise itself but also accordance with the requirements of documents, such as Regulations of the people's Liberation Army on the administration of qualification examination of equipment manufacturing units and Regulation on Licensing Administration of Scientific Research and Production of Arms and Equipment. The enterprises to be enlisted in the military purchase system must be non-foreign-holding enterprises that have been established in the territory of the People's Republic of China for more than three years, and their legal representatives or actual controllers must be of Chinese nationality. The quality management system must have been operated for more than three months. These enterprises must have had no serious violation of laws or dishonesty and no strict record of delayed delivery in the past three years. Moreover, the indicator system constructed in this paper meets most of the conditions of CMEE-MPM. Several conditions, such as the confidentiality system, financial management system, and measurement management system, are not considered in this paper and thus are subjects that require further study.

Author Contributions: Conceptualization, J.X. and S.Z.; Formal analysis, S.Z.; Investigation, J.X.; Methodology, S.Z.; Writing-original draft, S.Z.; Writing_-review and editing, S.Z.; Supervision: J.X. All authors have read and agreed to the published version of the manuscript.

Funding: This research was funded by the Natural Science Foundation of Heilongjiang Province (LH2019G014), the Philosophy and Social Science Research Planning Project of Heilongjiang Province (17JYH49), the Key Research Topics of Economic and Social Development in Heilongjiang Province(19023), the 2019 Annual Basic Project of the Party's Political Construction Research Center of the Ministry of Industry and Information Technology (19GZY411), the National Natural Science Foundation on Emergency Management Project of China (71841054), and the project of Central University Basic Research Fund (33072020CFT0902).

Conflicts of Interest: The authors declare no conflict of interest. 


\section{Appendix A}

Table A1. Indicator system for CMEE-MPM capabilities.

\begin{tabular}{|c|c|c|c|c|}
\hline The Goal & Category & Constraint & Criterion & Index \\
\hline \multirow{31}{*}{$\begin{array}{l}\text { The CMEE-MPM } \\
\text { capabilities }\end{array}$} & \multirow{31}{*}{$\begin{array}{l}\text { Service support } \\
\text { process }\end{array}$} & \multirow{11}{*}{$\begin{array}{l}\text { Integrated management } \\
\text { capacity }\end{array}$} & \multirow{2}{*}{ Thoughts integration } & Management's willingness to enter military products market \\
\hline & & & & Employees' ideological understanding to enter the military products market \\
\hline & & & \multirow{3}{*}{ Administrative management } & Completeness of internal management system \\
\hline & & & & Perfect situation about organizational structure of enterprises \\
\hline & & & & Emergency response capability \\
\hline & & & \multirow{3}{*}{ Social recognition } & Position of enterprises in the industry \\
\hline & & & & Enterprise's prestige \\
\hline & & & & Value of enterprise customer satisfaction \\
\hline & & & \multirow{3}{*}{ Documents \&records management } & Acquisition of military standard documents \\
\hline & & & & Completeness of production operation instructions \\
\hline & & & & Traceability of process file records \\
\hline & & \multirow{4}{*}{ Enterprise financial capacity } & \multirow{2}{*}{ Operation capacity } & Proportion of R\&D investment in military-related products \\
\hline & & & & Inventory input ratio of military-related products \\
\hline & & & \multirow{2}{*}{ Achievable economic benefits } & Current economic benefits \\
\hline & & & & Long-term economic benefits \\
\hline & & \multirow{8}{*}{ Resource allocation capacity } & \multirow{4}{*}{ Infrastructure } & Production and operation environment \\
\hline & & & & Production equipment allocation situation \\
\hline & & & & Test equipment allocation situation \\
\hline & & & & Maintenance equipment allocation situation \\
\hline & & & \multirow{4}{*}{ Staffing allocation } & R\&D staffing allocation situation \\
\hline & & & & Production staffing allocation situation \\
\hline & & & & Test personnel allocation situation \\
\hline & & & & Maintenance staffing allocation situation \\
\hline & & \multirow{8}{*}{ Quality management capacity } & \multirow{3}{*}{ System execution capacity } & Management review \\
\hline & & & & Internal audit \\
\hline & & & & External audit \\
\hline & & & \multirow{2}{*}{ Continuous improvement capacity } & Completion rate of corrective and preventive measures \\
\hline & & & & Continuous improvement project completion rate on schedule \\
\hline & & & \multirow{3}{*}{ Process management capacity } & Misjudgment rate of raw material inspection \\
\hline & & & & Non-conformity control rate of delivered products \\
\hline & & & & $\mathrm{r}$ rate of one-time inspection of reworked and repaired $\mathrm{p}$ \\
\hline
\end{tabular}


Table A1. Cont.

\begin{tabular}{|c|c|c|c|c|}
\hline The Goal & Category & Constraint & Criterion & Index \\
\hline \multirow{19}{*}{$\begin{array}{l}\text { The CMEE-MPM } \\
\text { capabilities }\end{array}$} & \multirow{19}{*}{$\begin{array}{l}\text { Product realization } \\
\text { process }\end{array}$} & \multirow{6}{*}{$R \& D$ and process capacity } & \multirow{4}{*}{ R\&D capacity } & Qualification rate of disposable sample delivery \\
\hline & & & & Transforming ability of scientific and technological achievements \\
\hline & & & & Design schedule punctuality rate \\
\hline & & & & Design error rate \\
\hline & & & \multirow{2}{*}{ Process capacity } & Timeliness of contract review \\
\hline & & & & Error rate of contract review \\
\hline & & \multirow{4}{*}{$\begin{array}{c}\text { Purchasing and } \\
\text { warehousing capacity }\end{array}$} & \multirow{2}{*}{ Procurement } & Qualification rate of raw material purchase \\
\hline & & & & Timely arrival rate of raw materials \\
\hline & & & \multirow{2}{*}{ Materials } & Accuracy of raw material distribution \\
\hline & & & & Stock error rate of raw materials \\
\hline & & \multirow{5}{*}{$\begin{array}{c}\text { Production and } \\
\text { manufacturing capacity }\end{array}$} & \multirow{3}{*}{ Production process } & Process rework rate \\
\hline & & & & Product delivery rate on time \\
\hline & & & & Qualification rate of one-time delivery of products \\
\hline & & & \multirow{2}{*}{ Equipment management } & Failure rate of key equipment \\
\hline & & & & Failure rate of main equipment \\
\hline & & \multirow{4}{*}{$\begin{array}{l}\text { Maintenance and } \\
\text { after-sales service } \\
\text { guarantee capacity }\end{array}$} & \multirow{2}{*}{ After-sale service } & Serving on time \\
\hline & & & & Post-service satisfaction \\
\hline & & & \multirow{2}{*}{ After-sales guarantee } & Reserve of after-sales spare parts \\
\hline & & & & Reserve of after-sale finished products \\
\hline
\end{tabular}


Table A2. The indicator weights for each level.

\begin{tabular}{|c|c|c|c|c|c|c|c|c|}
\hline The Goal & Category & weights & Constraint & weights & Criterion & weights & Index & weights \\
\hline \multirow{23}{*}{$\begin{array}{l}\text { CMEE-MPM } \\
\text { capabilities }\end{array}$} & \multirow{23}{*}{$\begin{array}{l}\text { Service support } \\
\text { process }\end{array}$} & \multirow{23}{*}{0.2759} & \multirow{11}{*}{$\begin{array}{c}\text { Integrated } \\
\text { management capacity }\end{array}$} & \multirow{11}{*}{0.3708} & \multirow[t]{2}{*}{ Thoughts integration } & \multirow[t]{2}{*}{0.0675} & $\begin{array}{c}\text { Management's willingness to enter military products } \\
\text { market }\end{array}$ & 0.8806 \\
\hline & & & & & & & $\begin{array}{l}\text { Employees' ideological Understanding to enter } \\
\text { military products market }\end{array}$ & 0.1194 \\
\hline & & & & & \multirow{3}{*}{$\begin{array}{l}\text { Administrative } \\
\text { management }\end{array}$} & \multirow{3}{*}{0.5252} & Completeness of internal management system & 0.5745 \\
\hline & & & & & & & $\begin{array}{c}\text { Perfect situation about organizational structure of } \\
\text { enterprises }\end{array}$ & 0.2633 \\
\hline & & & & & & & Emergency response capability & 0.1622 \\
\hline & & & & & \multirow{3}{*}{ Social recognition } & \multirow{3}{*}{0.1539} & Position of enterprises in the industry & 0.1544 \\
\hline & & & & & & & Enterprise's prestige & 0.4160 \\
\hline & & & & & & & Value of enterprise customer satisfaction & 0.4297 \\
\hline & & & & & \multirow{3}{*}{$\begin{array}{l}\text { Documents \&records } \\
\text { management }\end{array}$} & \multirow{3}{*}{0.2534} & Acquisition of military standard documents & 0.1200 \\
\hline & & & & & & & Completeness of production operation instructions & 0.3351 \\
\hline & & & & & & & Traceability of process file records & 0.5449 \\
\hline & & & \multirow{4}{*}{$\begin{array}{l}\text { Enterprise financial } \\
\text { capacity }\end{array}$} & \multirow{4}{*}{0.1205} & \multirow[t]{2}{*}{ Operation capacity } & \multirow[t]{2}{*}{0.3038} & $\begin{array}{l}\text { Proportion of R\&D investment in military-related } \\
\text { products }\end{array}$ & 0.8261 \\
\hline & & & & & & & Inventory input ratio of military-related products & 0.1739 \\
\hline & & & & & \multirow{2}{*}{$\begin{array}{l}\text { Achievable economic } \\
\text { benefits }\end{array}$} & \multirow{2}{*}{0.6962} & Current economic benefits & 0.1702 \\
\hline & & & & & & & Long-term economic benefits & 0.8298 \\
\hline & & & \multirow{8}{*}{$\begin{array}{l}\text { Resource allocation } \\
\text { capacity }\end{array}$} & \multirow{8}{*}{0.1205} & \multirow{4}{*}{ Infrastructure } & \multirow{4}{*}{0.5000} & Production and operation environment & 0.4082 \\
\hline & & & & & & & Production equipment allocation situation & 0.3122 \\
\hline & & & & & & & Test equipment allocation situation & 0.1528 \\
\hline & & & & & & & Maintenance equipment allocation situation & 0.1267 \\
\hline & & & & & \multirow{4}{*}{ Staffing allocation } & \multirow{4}{*}{0.5000} & R\&D staffing allocation situation & 0.5527 \\
\hline & & & & & & & Production staffing allocation situation & 0.2415 \\
\hline & & & & & & & Test personnel allocation situation & 0.1175 \\
\hline & & & & & & & Maintenance staffing allocation situation & 0.0884 \\
\hline
\end{tabular}


Table A2. Cont.

\begin{tabular}{|c|c|c|c|c|c|c|c|c|}
\hline The Goal & Category & weights & Constraint & weights & Criterion & weights & Index & weights \\
\hline \multirow{27}{*}{$\begin{array}{l}\text { CMEE-MPM } \\
\text { capabilities }\end{array}$} & & & & & & & Management review & 0.5792 \\
\hline & & & & & System execution capability & 0.3333 & Internal audit & 0.0899 \\
\hline & & & & & & & External audit & 0.3309 \\
\hline & & & Quality management & (2018 & & & $\begin{array}{c}\text { Completion rate of corrective and preventive } \\
\text { measures }\end{array}$ & 0.7681 \\
\hline & & & capacity & 0.3013 & capability & 0.3333 & $\begin{array}{l}\text { Continuous improvement project completion rate on } \\
\text { schedule }\end{array}$ & 0.2319 \\
\hline & & & & & & & Misjudgment rate of raw material inspection & 0.0845 \\
\hline & & & & & Process management & 03333 & Non-conformity control rate of delivered products & 0.7489 \\
\hline & & & & & & & $\begin{array}{l}\text { Qualification rate of one-time inspection of reworked } \\
\text { and repaired products }\end{array}$ & 0.1665 \\
\hline & \multirow{19}{*}{$\begin{array}{l}\text { Product } \\
\text { realization } \\
\text { process }\end{array}$} & \multirow{19}{*}{0.7241} & \multirow{6}{*}{$\begin{array}{l}\text { R\&D and process } \\
\text { capability }\end{array}$} & \multirow{6}{*}{0.4041} & \multirow{4}{*}{ R\&D capability } & \multirow{4}{*}{0.7333} & Qualification rate of disposable sample delivery & 0.4110 \\
\hline & & & & & & & $\begin{array}{l}\text { Transforming ability of scientific and technological } \\
\text { achievements }\end{array}$ & 0.0695 \\
\hline & & & & & & & Design schedule punctuality rate & 0.1120 \\
\hline & & & & & & & Design error rate & 0.4075 \\
\hline & & & & & \multirow{2}{*}{ Process capacity } & \multirow{2}{*}{0.2667} & Timeliness of contract review & 0.1649 \\
\hline & & & & & & & Error rate of contract review & 0.8351 \\
\hline & & & \multirow{4}{*}{$\begin{array}{l}\text { Purchasing and } \\
\text { warehousing capacity }\end{array}$} & \multirow{4}{*}{0.0960} & \multirow{2}{*}{ Procurement } & \multirow{2}{*}{0.7419} & Qualification rate of raw material purchase & 0.6863 \\
\hline & & & & & & & Timely arrival rate of raw materials & 0.3137 \\
\hline & & & & & \multirow{2}{*}{ Materials } & \multirow{2}{*}{0.2581} & Accuracy of raw material distribution & 0.6667 \\
\hline & & & & & & & Stock error rate of raw materials & 0.3333 \\
\hline & & & \multirow{5}{*}{$\begin{array}{l}\text { Production and } \\
\text { manufacturing } \\
\text { capacity }\end{array}$} & \multirow{5}{*}{0.3019} & \multirow{3}{*}{ Production process } & \multirow{3}{*}{0.5000} & Process rework rate & 0.0752 \\
\hline & & & & & & & Product delivery rate on time & 0.3836 \\
\hline & & & & & & & Qualification rate of one-time delivery of products & 0.5412 \\
\hline & & & & & \multirow{2}{*}{ Equipment management } & \multirow{2}{*}{0.5000} & Failure rate of key equipment & 0.7746 \\
\hline & & & & & & & Failure rate of main equipment & 0.2254 \\
\hline & & & \multirow{4}{*}{$\begin{array}{l}\text { Maintenance and } \\
\text { after-sales service } \\
\text { guarantee capability }\end{array}$} & \multirow{4}{*}{0.1980} & \multirow{2}{*}{ After-sale service } & \multirow{2}{*}{0.5000} & Serving on time & 0.5897 \\
\hline & & & & & & & Post-service satisfaction & 0.4103 \\
\hline & & & & & \multirow{2}{*}{ After-sales guarantee } & \multirow{2}{*}{0.5000} & Reserve of after-sales spare parts & 0.8049 \\
\hline & & & & & & & Reserve of after-sales finished products & 0.1951 \\
\hline
\end{tabular}




\section{References}

1. Zhang, Y.; Liu, J.; Zhang, J.; Wang, R. Emergy-based evaluation of system sustainability and ecosystem value of a large-scale constructed wetland in North China. Environ. Monit. Assess. 2013, 185, 5595-5609. [CrossRef]

2. Morandín-Ahuerma, I.; Contreras-Hernández, A.; Ayala-Ortiz, D.A.; Pérez-Maqueo, O. Socio-Ecosystemic Sustainability. Suatainability 2019, 11, 3354. [CrossRef]

3. Yang, D.; Chen, S.; Niu, W. A Comment on Four Representative Indexes of Sustainable Development. Sci. Manag. Res. 2001, 58-61, 72. [CrossRef]

4. Masocha, R. Social Sustainability Practices on Small Businesses in Developing Economies: A Case of South Africa. Sustainability 2019, 11, 3257. [CrossRef]

5. da Silva, J.; Fernandes, V.; Limont, M.; Dziedzic, M.; Andreoli, C.; Rauen, W.B. Water sustainability assessment from the perspective of sustainable development capitals: Conceptual model and index based on literature review. J. Environ. Manag. 2020, 254. [CrossRef]

6. Lein, J.K. Toward a Remote Sensing Solution for Regional Sustainability Assessment and Monitoring. Sustainability 2014, 6, 2067-2086. [CrossRef]

7. Zeng, Z.; Gu, P.; Zhang, M. The Application of Data Envelopment Analysis in the Evaluation of Sustainable Development. Syst. Eng. Theor. Pract. 2000, 8, 114-118. [CrossRef]

8. Zang, X.; Wang, Q.; Chen, T. The Construction of Sustainable Development Indicator System for Green Blocks in Eco-cities. City Plan Rev. 2017, 41, 68-75. [CrossRef]

9. Yan, M.; Odum, H.T. A Study on EmergyEvalution and Sustainabe Development of Tibetan Eco-economic System. J. Nat. Resour. 1998, 13, 116-125. [CrossRef]

10. Wang, J.; Geng, J. Empirical Study on Resources Exhausted City, Cability of Sustainable Development. Econ. Probl. 2012, 1, 46-49. [CrossRef]

11. Polonenko, L.M.; Hamouda, M.A.; Mohamed, M.M. Essential components of institutional and social indicators in assessing the sustainability and resilience of urban water systems: Challenges and opportunities. Sci. Total Environ. 2020, 708. [CrossRef] [PubMed]

12. Zhang, J. Dynamic simulation of regional sustainable tourism development system. Syst. Eng. Theor. Pract. 2011, 31, 2101-2107. [CrossRef]

13. Doukas, H.; Karakosta, C.; Psarras, J. Computing with words to assess the sustainability of renewable energy options. Expert Syst. Appl. 2010, 37, 5491-5497. [CrossRef]

14. Feng, Y.; Han, W.; Wang, H.; Lian, J. Study on the Sustainable Development Oriented Optimal Allocation to Region Water Resources. Syst. Eng. Theor. Pract. 2003, 2, 133-138. [CrossRef]

15. Wagner, M. The role of corporate sustainability performance for economic performance: A firm-level analysis of moderation effects. Ecol. Econ. 2010, 69, 1553-1560. [CrossRef]

16. Tomšič, N.; Bojnec, Š.; Simčič, B. Corporate sustainability and economic performance in small and medium sized enterprises. J. Clean. Prod. 2015, 108. [CrossRef]

17. Cai, W. Research on the cultivation of financial ability based on the sustainable development of enterprises. Hubei Soc. Sci. 2011, 3, 71-74. [CrossRef]

18. Moffat, A.; Auer, A. Corporate Environmental Innovation (CEI): A government initiative to support corporate sustainability leadership. J. Clean. Prod. 2006, 14, 589-600. [CrossRef]

19. Li, R.; Peng, C.; Yang, X. Dual Innovation and Corporate Sustainable Development: The Mediating Role of Short-Term Financial Performance and Long-Term Competitive Advantage. Sci. Technol. Prog. Policy 2019, 36, 81-89. [CrossRef]

20. Lodhia, S.; Martin, N. Corporate Sustainability Indicators: An Australian Mining Case Study. J. Clean. Prod. 2014, 84, 107-115. [CrossRef]

21. Liern, V.; Pérez-Gladish, B. Ranking corporate sustainability: A flexible multidimensional approach based on linguistic variables. Int. Trans. Oper. Res. 2017, 25, 1-20. [CrossRef]

22. Garcia, S.; Cintra, Y.; Rita de Cássia, S.R.; Lima, F.G. Corporate sustainability management: A proposed multi-criteria model to support balanced decision-making. J. Clean. Prod. 2016, 136, 181-196. [CrossRef]

23. Long, Y.; Pan, J.; Feng, T. The Impact Research of the Lean Production and Corporate Environmental Management on Manufacturing's Sustainability Performance. Soft Sci. 2018, 220, 68-71. [CrossRef]

24. Kitsios, F.; Kamariotou, M.; Talias, M.A. Corporate Sustainability Strategies and Decision Support Methods: A Bibliometric Analysis. Sustainability 2020, 12, 521. [CrossRef] 
25. Strachan, H. Making strategy: Civil-military relations after Iraq. Survival 2006, 48, 59-82. [CrossRef]

26. Huntington, S.P. The Soldier and the State: The Theory and Politics of Civil-Military Relations; Harvard University Press: Cambridge, MA, USA, 1957.

27. Feaver, P.D. Armed Servants: Agency, Oversight and Civil-Military Relations; Harvard University Press: Cambridge, MA, USA, 2003.

28. Feaver, P.; Kohn, R. (Eds.) Soldiers and Civilians: The Civil-Military Gap and American National Security; MIT Press: Cambridge, MA, USA, 2001; pp. 289-324.

29. Egnell, R. Explaining US and British performance in complex expeditionary operations: The civil-military dimension. J. Strateg. Stud. 2006, 29, 1041-1075. [CrossRef]

30. Edwards, J.R. Accounting for Fair Competition between Private and Public Sector Armaments Manufacturers in Victorian Britain. Abacus 2015, 51, 412-436. [CrossRef]

31. Byrne, E.F. Assessing Arms Makers' Corporate Social Responsibility. J. Bus. Ethics 2007, 74, 201-217. [CrossRef]

32. Akcinaroglu, S.; Radziszewski, E. Private Military Companies, Opportunities, and Termination of Civil Wars in Africa. J. Confl. Resolut. 2013, 57, 795-821. [CrossRef]

33. Mahoney, C.W. Buyer Beware: How Market Structure Affects Contracting and Company Performance in the Private Military Industry. Secur. Stud. 2017, 26, 30-59. [CrossRef]

34. Vie, L.L.; Scheier, L.M.; Lester, P.B.; Ho, T.E.; Labarthe, D.R.; Seligman, M.E.P. The U.S. Army Person-Event Data Environment: A Military-Civilian Big Data Enterprise. Big Data 2015, 3, 67-79. [CrossRef]

35. Moore, E.E.; Knudson, M.M.; Schwab, C.W.; Trunkey, D.D.; Johannigman, J.A.; Holcomb, J.B. Military-civilian collaboration in trauma care and the senior visiting surgeon program. N. Engl. J. Med. 2007, 357, 2723-2727. [CrossRef]

36. Schwab, C.W. Winds of War: Enhancing Civilian and Military Partnerships to Assure Readiness: White Paper. J. Am. Coll. Surg. 2015, 221, 235-254. [CrossRef]

37. TeKulve, H.; Smit, W.A. Civilian-military co-operation strategies in developing new technologies. Res. Policy 2003, 32, 955-970. [CrossRef]

38. Watkins, T.A. Beyond guns and butter: Managing dual-use technologies. Technovation 1990, 10, 389-406. [CrossRef]

39. Cronberg, T. Civil Reconstructions of Military Technology: The United States and Russia. J. Peace Res. 1994, 31, 205-218. [CrossRef]

40. Brandt, L. Defense Conversion and Dual-Use Technology: The Push toward Civil-Military Integration. Policy Stud. J. 1994, 22, 359-370. [CrossRef]

41. Molas-Gallart, J. Which way to go? Defence technology and the diversity of 'dual-use' technology transfer. Res. Policy 1997, 26, 367-385. [CrossRef]

42. Lee, B.K.; Sohn, S.Y. Exploring the effect of dual use on the value of military technology patents based on the renewal decision. Scientometrics 2017, 112, 1203-1227. [CrossRef]

43. Wilhite, A.; Burns, L.; Patnayakuni, R.; Tseng, F. Military supply chains and closed-loop systems: Resource allocation and incentives in supply sourcing and supply chain design. Int. J. Prod. Res. 2014, 52, 1926-1939. [CrossRef]

44. Sanchez-Andres, A. Arms exports and restructuring in the Russian defence industry. Eur. Asia Stud. 2004, 56, 687-706. [CrossRef]

45. Zhao, C.; Ji, P.; Liu, J.; Zhang, H.; Wang, Y. Civil-Military Integration in Some Typical Countries. Sci. Sci. Manag. S. ET. 2005, 10, 26-31. [CrossRef]

46. Peng, Z.; Han, R. International reference and policy options about civil-military integration driving the development of recently emerging industries. Reform. 2017, 9, $27-37$.

47. Tan, Q.; Yang, L.; Ng, J.C.Y. References and Implications of Foreign Civil-Military Integration Models. J. Nanjing Univ. Sci. Technol. (Soc. Sci. Ed.). 2018, 31, 12-15.

48. Zhu, Z. On the Enactment of the Basic Law of the Civil-military Integration Development in China. J. Beijing Inst. Technol. (Soc. Sci. Ed.) 2016, 18, 133-139. [CrossRef]

49. You, G.; Yan, H.; Zhao, X. The Policy System Construction on the Development of Civil-military Integration: Quo Status, Problems and Countermeasures. Forum Sci. Technol. China 2017, 1, 150-156. [CrossRef]

50. Chen, H.; Huang, C.; Zhao, L.; Wang, J.; Wei, P. Science and technology policy of military and civilian integration. Def. Technol. Rev. 2018, 39, 62-69. [CrossRef] 
51. Wang, Y.; Sun, L. The Unification of Military-Civilian Integration and National Strategic System. Theor. Reform. 2018, 4, 70-78. [CrossRef]

52. Du, R.; Ma, Y. Research on Military and Civilian Integration Level Measurement and countermeasures in Defense Industry. Sci. Technol. Prog. Policy 2016, 33, 108-116. [CrossRef]

53. Du, R.; Guo, W. Research on Military and Civilian Integration Efficiency and Measurement in the Defense Industry. Sci. Technol. Prog. Policy 2017, 34, 106-111. [CrossRef]

54. Du, R. Civil-Military integration system of defense industry equipment construction and its building. Forum Sci. Technol. China 2018, 5, 113-120.

55. Zhang, L.; Hu, H.; Li, Z. Research and Development Policies of China's Dual-Use Technology under Civil-Military Integration. Forum Sci. Technol. China 2018, 5, 121-127. [CrossRef]

56. Cheung, T.M. Innovation in China's Defense Technology Base: Foreign Technology and Military Capabilities. J. Strateg. Stud. 2016, 39, 1-34. [CrossRef]

57. Fang, W.; Wang, C. The Cooperative Stability Evolutionary Game Analysis of the Military-Civilian Collaborative Innovation for China's Satellite Industry. Math. Probl. Eng. 2019, 3, 1-17. [CrossRef]

58. Du, D.; Kang, M.; Yang, X. Research on the Construction of Innovative Driving System in the Development of Military and Civilian Integration. Econ. Rev. 2017, 4, 48-53. [CrossRef]

59. Dong, X.; Zhang, W. On impetus of collaborative innovation of Dual-use technological industrial cluster. Sci. Manag. Res. 2014, 32, 1-5. [CrossRef]

60. Zhao, L.-M.; Sun, J.-H.; Zhang, H.-B. Technology sharing behavior in civil-military integration collaborative innovation system based on differential game. J. Ind. Eng. Eng. Manag. 2017, 31, 183-191. [CrossRef]

61. Suo, C. The Evaluation Research on the Scientific and Technological Collaborative Innovation Mechanism in Military and Civilian Integration Enterprises. Sci. Technol. Manag. Res. 2018, 9, 1-8. [CrossRef]

62. Fang, W.; Xiao, L.; Yang, B.; Wang, L. An empirical study of influencing factors on civil-involved military knowledge transfer: A perspective of civil-military integration collaborative innovation. Stud. Sci. Sci. 2019, 37, 664-678.

63. Li, Y.L.; Guo, A.D.; Luo, S.J. Research on Management of Emergency Supplies Reserves for Integrated Military-Civilian. Appl. Mech. Mater. 2012, 201-202, 987-990. [CrossRef]

64. Zheng, Y.-J.; Wang, Y.; Ling, H.-F.; Xue, Y.; Chen, S.-Y. Integrated civilian-military pre-positioning of emergency supplies: A multiobjective optimization approach. Appl. Soft Comput. 2017, 58, 732-741. [CrossRef]

65. Weidenbaum, M.L. The military market in the 1960's. Bus. Horiz. 1961, 4, 61-68. [CrossRef]

66. Weidenbaum, M.L. The Scope of the Military Market. J. Mark. 1959, 24, 17-20. [CrossRef]

67. Desjardins, D.D.; Hopper, D.G. Military market for flat panel displays. Proc. SPIE 1997, 3057, 39-50. [CrossRef]

68. Petersohn, U. The social structure of the market for force. Coop. Confl. 2015, 50, 269-285. [CrossRef]

69. Wu, X. Constraints and Countermeasures of world military trade. Manag. World. 1992, 6, 179-182. [CrossRef]

70. Zhang, W.; Zheng, X. A Game Analysis for Oligopoly Military Products Market. Syst. Eng. 2010, $28,54-57$.

71. Bai, F.; Du, W.; Li, H.; Wang, X. Research on the Military Products Market Access System in China. J. Acad. Equip. 2013, 24, 29-32. [CrossRef]

72. Zhang, L.; Wei, F.; Lu, S. Study on Marketing Strategy for Aviation Manufacturing Enterprise Based on Domestic Military Market. Ind. Eng. Manag. Rec. 2015, 543-546. [CrossRef]

73. Jiang, Y.; Xie, W.; Qu, L. Game-based Profit Analysis for Private Enterprises in Military Market. J. Acad.Equip. 2016, 27, 80-84. [CrossRef]

74. Li, M.; Chen, B. Government Investment, the Military-Civilian Industrial Standards Discrepancy, and the Plight of Civil Manufacturer Entering the Military Product Market. Nankai Econ. Stud. 2019, 1, 25-45. [CrossRef]

75. Parente, F.; Anderson, P.J. Delphi inquiry systems. In Judgmental Forecasting; John Wiley and Sons: New York, NY, USA, 1987; pp. 129-156.

76. Liu, P.; Wu, M. Fuzzy Theory and Its Application; National University of Defense Technology Press: Changsha, China, 1998; pp. 201-209.

(C) 2020 by the authors. Licensee MDPI, Basel, Switzerland. This article is an open access article distributed under the terms and conditions of the Creative Commons Attribution (CC BY) license (http://creativecommons.org/licenses/by/4.0/). 